\title{
SEGMENTARIDADES E MOVIMENTOS NEGROS NAS ELEIÇÕES DE ILHÉUS*
}

Marcio Goldman

Ao escrever sobre o "movimento negro na Bahia", Michel Agier observa a existência, na sociedade brasileira em geral, de "uma concorrência e de uma relação entre diversos modos de identificação social, seja no plano coletivo, seja no decorrer de cada história individual" (Agier 1992:54). Deveríamos, talvez, observar que essa pluralidade não é de forma alguma exclusiva de um contexto social ou sistema cultural específico, e lembrar, com Michel Serres (1997), que as "identidades" são sempre o resultado do empobrecimento de um número infinito de "pertencimentos" (a uma família, a um gênero, a um país...) a que todos estamos submetidos.

Por outro lado, é óbvio que essa pluralidade identitária não é obstáculo para a análise, e Agier não tem dificuldade em demonstrar as "homologias formais" entre os grupos e movimentos que compõem o "mundo negro" de Salvador (Agier 1992:76): todos se representam a partir de um modelo genealógico, que funcionaria por segmentação e que teria na pureza seu critério valorativo fundamental (Agier 1992:76-77). No caso dos blocos afro de Salvador - mas o mesmo seria verdadeiro para os terreiros de candomblé - , "cada bloco nasce de um outro", e "o Ilê Aiyê é [...] reconhecido como o ancestral de todos os blocos" (Agier 1992:61), já que, fundado em 1973, é visto como tendo dado origem, por fissões sucessivas ou simultâneas, aos principais blocos afro de Salvador: Olodum (1979), Malê Debalê (1979), Ara Ketu (1980) e Muzenza (1981), para ficarmos apenas nos mais conhecidos (ver Cunha 1991:290, 296; G oli 1998: 104-109; Lima 1998: 164-166; Morales 1991:80; Schaeber 1998: 146; Veiga 1998:123-124; ver, também, Risério 1981).

Por outro lado, Agier (1992:73-74) observa que além da segmentação, uma "tendência federalizante" atuaria no sentido de agrupar os blocos em Conselhos e Associações (e os terreiros em Federações). Mesmo princípio que gerou, por exemplo, o Movimento Negro Unificado Contra a Discriminação e o Racismo (MNU), criado em 1978 para funcionar como 
pólo unificador dos vários grupos negros existentes no país (Valente 1986:29-30) - ambição aparentemente não realizada (Cunha 1998:235).

Se Agier parece contornar habilmente a conhecida associação dos blocos (e dos terreiros) com a política partidária ${ }^{1}$, Morales aborda com cuidado a questão, mostrando que, à medida que se convertem em "grupos culturais" e buscam desenvolver atividades ligadas ao seu bairro ou grupo social, os blocos tendem a se tornar parte do jogo do clientelismo político (Morales 1988:267, 270-273; 1991:84). Isso tanto porque organizações locais buscam diversificar suas relações políticas (McCallum 1996:226, nota 9), quanto, como observa C unha (1998:231-232), porque as formas de organização baseadas na "identidade" tendem a escamotear tensões e diferenças internas bem como, eu acrescentaria, a apresentar, simultaneamente, uma maior maleabilidade no que diz respeito a alianças com forças políticas de outra ordem.

O que é verdadeiro para Salvador, não parece sê-lo menos para Ilhéus, linda cidade de porte médio situada na chamada microrregião cacaueira, no sul do Estado da Bahia, de onde provém o material empírico aqui utilizado ${ }^{2}$. Esse material resulta de uma pesquisa, desenvolvida desde 1996, que tenta, basicamente, estudar a política (no sentido de política partidária e de Estado) em Ilhéus, encarando-a do ponto de vista do movimento negro da cidade. Mais que simples questão estilística, creio que esta é uma opção metodológica e epistemológica fundamental. Se a antropologia se desenvolveu buscando estudar " outras sociedades" de um ponto de vista a elas imanente, uma de suas dificuldades, quando se volta para o estudo da "sociedade do observador", parece ser a incapacidade de manter esse descentramento de perspectiva que sempre a caracterizou. As alternativas mais usuais são a busca, no interior da sociedade do analista, de fenômenos capazes de apresentar alguma alteridade em relação às forças dominantes (o que sempre implica o risco de privilegiar o inessencial), ou a análise de certos fenômenos, reduzindo-os àqueles que a antropologia costuma privilegiar (o que comporta a ameaça de tratar o essencial como inessencial), ou de manter a perspectiva dominante (o que pode provocar a perda da originalidade da abordagem antropológica).

C reio que outra possibilidade para a " antropologia das sociedades complexas” é manter o foco tradicional da disciplina nas instituições centrais da sociedade estudada, e buscar, através de uma espécie de "desvio etnográfico”, um ponto de vista descentrado. No caso da política, tratarse-ia de encarar as representações nativas sobre os processos políticos dominantes como verdadeiras teorias políticas, produzidas por observadores suficientemente deslocados em relação ao objeto para que possam 
produzir visões realmente alternativas, e de usar tais representações e teorias como guias para a análise antropológica. Isso significa que não pretendo realizar um estudo antropológico do movimento negro de Ilhéus (para o qual deve-se consultar Silva 1998, cap. 3), mas da política na cidade, orientando essa investigação pela perspectiva cética e descentrada que o movimento negro tem a seu respeito.

A "genealogia" dos blocos afro de Ilhéus é organizada a partir de uma origem dupla. De um lado, o Le Gue D'Pá, fundado em 1980, que deu origem ao Gangas (1986), que deu origem ao Malês (1986) e ao Zambi Axé (1994); este, por sua vez, deu origem ao Guerreiros de Zulu (1999). De outro lado, fundado em 1982 por um membro do Ilê Aiyê, temos o MiniCongo, do qual se originaram: Axé Odara (1984), que gerou o Dilazenze (1986); Rastafari (1984), que gerou o Raízes Negras (1990), que gerou o D'Logun (1993); o Zimbabuê (1985), que gerou o Danados do Reggae (1990), que gerou o Leões do Reggae (1998); e o Força Negra (1988).

Alguns desses blocos (Le Gue D’Pá, Axé Odara, Gangas) não mais existem; o Malês, o Força Negra e o Zimbabuê têm uma existência intermitente; o Leões do Reggae ainda não conseguiu se estabelecer plenamente; os demais (sete ou oito, já que o Raízes Negras e o D'Logun estão constantemente se fundindo e se separando) formam o núcleo do " mundo negro" de Ilhéus, ao lado de um ou dois afoxés, alguns grupos de capoeira e duas escolas de samba, hoje praticamente inexistentes, mas sempre mencionadas e colocadas na origem da linha dos blocos que se inicia com o Mini-Congo.

Cada bloco possui um enraizamento territorial: quatro deles (Dilazenze, Rastafari, Raízes Negras e D'Logun) ficam na Conquista, o bairro mais populoso de Ilhéus, situado em um morro próximo ao centro da cidade, de população pobre e ampla maioria negra; dois blocos (Zambi Axé e Guerreiros de Zulu) ficam no Malhado, outro grande bairro pobre e de população majoritariamente negra; o Danados do Reggae fica na Nova Brasília (enclave pobre no bairro de classe média do Pontal); e o MiniCongo fica no Oiteiro de São Sebastião (também um enclave pobre no Centro da cidade).

As rupturas que dão origem aos blocos são atribuídas a brigas entre seus componentes, a maior parte ligada a problemas financeiros e/ou desentendimentos sobre a organização do bloco ${ }^{3}$. Além disso, cada um deles esteve, está - e provavelmente estará - de alguma forma ligado a políticos profissionais que ou participaram de sua fundação, ou se aproximaram posteriormente, ou o fazem próximo às eleições. A pesar das constantes tentativas de união em torno de candidatos comuns, alianças 
laterais com diferentes políticos provocam a divisão dos blocos no período eleitoral. Ao lado desses processos de divisão, há também exemplos da "tendência federalizante" de que fala Agier: seja nas tentativas, sempre recomeçadas, de constituir e fazer funcionar o Conselho de Entidades Afro-Culturais (CEAC), seja na quase "mítica" eleição municipal de 1982, quando, por razões que serão mencionadas adiante, todos os blocos e grupos do movimento negro teriam se unido (ver G oldman 2000).

Mesmo essa brevíssima descrição permite perceber que à origem "genealógica" dos blocos afro de Ilhéus se soma a percepção de sua história em termos de "segmentação" e de alianças laterais. Ora, o objetivo central deste trabalho é contribuir para a compreensão da política de nossa sociedade (no sentido de política partidária e de Estado) de um ponto de vista propriamente antropológico. Isto passa, creio, pela elaboração de uma perspectiva que leve a sério o que os agentes sociais efetivamente fazem e dizem, e, ao mesmo tempo, seja capaz de conferir aos dados um tipo de organização que acrescente algo às apreensões necessariamente parciais a que a vida social nos condena. Não certamente no sentido de alguma espécie de totalidade transcendente e englobante, mas como forma de articular as situações que estudamos a fim de torná-las simultaneamente inteligíveis e aptas a conferir inteligibilidade a outras tantas situações mais ou menos similares. Em resumo, trata-se aqui de propor a introdução do conceito de segmentaridade na análise da política de sociedades dotadas de Estado.

\section{Eleições}

A política em Ilhéus sempre tendeu a ser comandada por uma elite local que, dada a natureza quase exclusiva de sua atividade econômica, ficou conhecida como sendo formada pelos "coronéis do cacau" : as poucas famílias que, durante mais de um século, dominaram economicamente o município, nele também exerceram o poder político. Assim, até 1976, dos 24 intendentes e prefeitos de Ilhéus dezenove podem ser encontrados entre os principais fazendeiros e comerciantes locais (ver Falcón 1995: 122 $123,128,139-140)$. Nas eleições municipais realizadas naquele ano, nos quadros do bipartidarismo imposto pelo regime militar, essa situação se repetiu: Antônio Olímpio Rehen da Silva, à frente de uma das duas sublegendas do antigo Movimento Democrático Brasileiro (MDB), venceu as eleições contra Herval Soledade, candidato da mais votada das três sublegendas da Aliança Renovadora Nacional (ARENA). Tanto Antônio Olím- 
pio quanto Herval Soledade faziam parte de famílias que vinham controlando a política de Ilhéus desde o final do século XIX. Menos observado na ocasião foi o fato de que na outra sublegenda do MDB (encabeçada por Jorge Viana) aparecia como candidato a vice-prefeito um certo Jabes Ribeiro, jovem político de 23 anos de idade. Filho de um motorista, Jabes (como é até hoje conhecido na cidade) não se adequava ao perfil histórico dos principais políticos locais. Estudante de direito, ocupa a sublegenda que, em manobra clássica do sistema bipartidário de então, visa tanto acomodar forças partidárias minoritárias quanto atrair votos que a legenda principal dificilmente obteria.

Eleita a chapa de Antônio Olímpio, procedeu-se, como sempre, à divisão dos cargos municipais. Professor de física e química, Jabes Ribeiro é indicado para a Secretaria Municipal de Educação. Em 1982, Antônio Olímpio desincompatibiliza-se do cargo para concorrer, sem sucesso, a uma cadeira na Assembléia Legislativa. O vice-prefeito assume e apóia o nome de Jabes Ribeiro para a prefeitura nas eleições de 1982. Com uma campanha centrada em termos como "mudança", "renovação", "povo" etc., Jabes, com apenas 29 anos e vinculado ao chamado MDB " autêntico”, vence as eleições por uma ampla margem de votos, derrotando o candidato ligado às famílias mais tradicionais da cidade (que consideram sua eleição um desastre).

Em 1986, em meio aos problemas econômicos provenientes da "crise do cacau" e enfrentando suspeitas de corrupção de alguns de seus assessores mais próximos, Jabes lança a candidatura de João Lírio à Assembléia Legislativa. Lírio é eleito, o que lhe confere cacife político para ser lançado pelo prefeito candidato à sua sucessão em 1988. Vitorioso, Lírio assume a prefeitura, enquanto Jabes é nomeado para a Secretaria Estadual do Trabalho no governo Waldir Pires, e, em 1990, se elege deputado federal.

As eleições municipais de 1992 colocam em oposição direta dois antigos quase-aliados. Após a vitória de Jabes Ribeiro em 1982 e a derrota de Antônio Olímpio para a Assembléia Legislativa no mesmo ano, este último se afasta do antigo MDB e inicia um movimento de aproximação com o grupo político liderado por Antônio Carlos Magalhães, que logo fundaria o Partido da Frente Liberal (PFL). É por este partido que se lança candidato à prefeitura de Ilhéus em 1992, concorrendo com Jabes Ribeiro, que, após apoiar a candidatura de Luiz Inácio Lula da Silva no segundo turno das eleições presidenciais de 1989, abandona o PMDB e ingressa, em 1990, no Partido da Social Democracia Brasileira (PSDB).

A proveitando a avaliação negativa do governo João Lírio, o governo estadual investe diretamente nas eleições de Ilhéus, apoiando o nome de 
Antônio Olímpio. A operação é montada a partir do "compromisso", ou "promessa", de transformar o município em uma Zona de Processamento de Exportações (ZPE), que geraria " mais de 10.000 empregos" - possibilidade muito atraente em um contexto de taxas de desemprego crescentes em função da conjuntura nacional e da "crise do cacau" no plano local. A vitória é de Antônio Olímpio, mais uma vez eleito derrotando Jabes Ribeiro e Ruy Carvalho, candidato de uma frente de partidos de esquerda.

A população de Ilhéus é quase unânime em sustentar que, entre os principais fatores que teriam determinado o resultado da eleição de 1992, estava o mau desempenho do governo João Lírio, além da proposta de criação da ZPE com seus 10 mil postos de trabalho. Praticamente, a mesma unanimidade pode ser constatada a respeito do segundo governo de Antônio Olímpio, considerado ainda pior que o de seu antecessor. O nãocumprimento das promessas eleitorais, a deterioração da cidade e a corrupção do governo seriam as causas dessa maciça rejeição. Se essa situação acabou fazendo com que Antônio Olímpio permanecesse à margem de seu próprio processo sucessório, o mesmo não ocorreu, é claro, com as forças políticas que o haviam apoiado em 1992.

Durante o primeiro semestre de 1996, três pré-candidaturas à prefeitura disputavam o apoio do governo do Estado da Bahia e do senador Antônio Carlos Magalhães: G umercindo Tavares, pelo Partido Trabalhista Brasileiro (PTB); Rúbia Carvalho, pelo Partido Social C ristão (PSC); Roland Lavigne, pelo Partido Liberal (PL). O primeiro, que nunca disputara uma eleição, fazia parte de uma das mais tradicionais famílias "cacaueiras" de Ilhéus, sendo chamado por alguns de "o último coronel". Rúbia Carvalho, filha e esposa de ricos comerciantes de cacau, havia se candidatado à Assembléia Legislativa em 1994, tendo obtido cerca de 4.600 votos em Ilhéus, o que, mesmo sem conseguir elegê-la, a transformava em potencial candidata à prefeitura. Roland Lavigne apresentava uma trajetória bastante distinta, tendo construído sua carreira política em municípios menores vizinhos a Ilhéus, Una e Camacan; elegeu-se deputado estadual em 1990 e montou um poderoso esquema político no sul e extremo sul baianos. Em 1994, foi o quarto deputado federal mais votado do Estado da Bahia, obtendo mais de um quarto dos votos válidos de Ilhéus. Depois de eleito, passou a enfrentar denúncias de malversação de recursos do Sistema Único de Saúde (SUS) e de esterilização indiscriminada de mulheres.

Os três pré-candidatos disputaram o apoio das autoridades estaduais e do senador Antônio Carlos Magalhães, que, finalmente, decidiram 
apoiar Roland Lavigne à frente de uma coligação que incluía os partidos de Gumercindo Tavares e Rúbia Carvalho, que deveriam, conseqüentemente, abrir mão de suas candidaturas. Em junho de 1996, G umercindo aceitou a decisão e partiu para uma longa viagem; Rúbia Carvalho, ao contrário, insistiu em se manter na disputa. O perfil "conservador" de sua candidatura, suas relações históricas com o grupo de Antônio Carlos Magalhães, sua aversão pessoal a Jabes Ribeiro, faziam crer que acabaria adotando a mesma solução de G umercindo Tavares; ela, no entanto, preferiu apoiar Jabes Ribeiro.

Após a derrota de 1992, Jabes Ribeiro retoma seu mandato de deputado federal; ao mesmo tempo, inicia articulações visando à sucessão municipal de 1996. No início de 1994, anuncia publicamente a decisão de não concorrer à reeleição para a Câmara, proclamando seu "compromisso histórico" e "opção preferencial" pela cidade de Ilhéus. Tendo definido a falta de apoio das esquerdas à sua candidatura em 1992 como uma das causas centrais de sua derrota, e buscando capitalizar sua atuação como deputado federal, bem como seu apoio a Lula tanto no segundo turno das eleições presidenciais de 1989 quanto no primeiro turno das eleições de 1994, Jabes procura articular uma ampla aliança e oferece a viceprefeitura ao Partido dos Trabalhadores (PT), que aceita. Além disso, obtém apoio, formal e informal, de mais seis partidos - além daquele de vários candidatos a vereador que, ligados a Rúbia Carvalho, acabaram permanecendo formalmente na coligação que apoiava Roland Lavigne. Jabes Ribeiro vence as eleições municipais de 1996 com mais de 20.000 votos de diferença sobre Roland Lavigne. Em janeiro de 1997, assume o cargo, com um vice do PT e Rúbia Carvalho como secretária municipal de Assistência Social.

A partir de maio de 1998, nova reviravolta política. Jabes Ribeiro inicia um processo de aproximação com o governo estadual e com Antônio Carlos Magalhães, tornando-se um dos líderes de um setor do PSDB baiano que decide não apenas apoiar a reeleição de Fernando Henrique Cardoso como também se aliar, no plano estadual, a Antônio Carlos Magalhães. Isso fez com que o PT rompesse a aliança com o prefeito e exigisse de seus membros o abandono dos cargos que ocupavam. O primeiro comício da campanha de Fernando Henrique Cardoso à reeleição é realizado no dia 21 de agosto justamente em Ilhéus, e conta, em seu palanque, com as presenças do presidente da República, do governador da Bahia, do então senador Antônio C arlos Magalhães, de Jabes Ribeiro, Rúbia Carvalho, Roland Lavigne e outros aliados, ex-aliados, futuros aliados, inimigos, ex-inimigos e futuros inimigos. 
Entretanto, a despeito dessas “ aproximações”, Jabes Ribeiro tratava de articular a candidatura de Rúbia Carvalho para as eleições legislativas de 1998. A ex-inimiga política pretendia recandidatar-se à Assembléia Legislativa, acreditando ter, dessa vez, um número suficiente de votos para se eleger. Jabes, contudo, manobrou no sentido de lançar seu nome para a Câmara dos Deputados, dando margem à interpretação de que visava basicamente reduzir o número de votos que Roland Lavigne obteria em Ilhéus. De fato, Rúbia C arvalho não se elegeu: obteve mais de 14.000 votos em Ilhéus, mas não chegou sequer à marca dos 20.000 em todo o estado; Roland Lavigne, por sua vez, reelegeu-se.

A derrota de Rúbia Carvalho em 1998 foi interpretada por seus assessores como uma espécie de "sacrifício" visando às eleições municipais de 2000, quando, supostamente, teria seu nome lançado para a prefeitura ou, na pior das hipóteses, para o cargo de vice-prefeita, caso Jabes Ribeiro decidisse tentar a reeleição. Esta foi a opção, e durante alguns meses o preenchimento do posto de vice-prefeito foi adiado, provocando boatos em torno de vários nomes, inclusive o de Rúbia Carvalho. No entanto, o fato de Rúbia agora pertencer ao partido do prefeito fazia com que seu nome não fosse visto como ideal para uma almejada aliança com antigos inimigos políticos que Jabes procura compor. Finalmente, no final de junho, revela-se que o candidato a vice-prefeito viria do PTB, partido aliado no plano estadual ao PFL, já que isso "sinalizaria a parceria" (termo sempre utilizado por Jabes para designar a aliança) entre governos municipal e estadual. No dia 28 de junho, Angela Maria Corrêa de Souza é anunciada como candidata a vice-prefeita na chapa de Jabes Ribeiro.

Logo após o anúncio de que o PTB preencheria o cargo de vice-prefeito, Rúbia Carvalho lança seu nome para a Câmara de Vereadores eleição tida como certa tanto pelos eleitores quanto por seus assessores. Estes, no entanto, confidenciam que a candidata havia ficado "deprimida" com a decisão de Jabes e que ela não demonstrava muito entusiasmo com a campanha para a vereança. Essa "depressão" parece ter se agravado muito quando o nome da vice foi finalmente divulgado: Angela era mulher, ligada a grupos cristãos e envolvida com atividades de "ação social”, possuindo exatamente o mesmo perfil político de Rúbia Carvalho.

A coligação "Ilhéus no Caminho Certo" - comandada por Jabes Ribeiro e envolvendo, além do PSDB e do PTB, mais sete partidos - era tida como franca favorita desde o início da campanha; seu principal adversário era o PFL, mais uma vez comandado por Roland Lavigne. Ao contrário do que acontecera em 1996, dessa vez tanto Jabes quanto Roland "disputavam" o apoio do governador do estado e do senador Antô- 
nio Carlos Magalhães. Essa rivalidade envolvia a obtenção de declarações explícitas de apoio (tanto o governador quanto o senador se manifestaram, ao longo da campanha, em favor dos dois candidatos) e, principalmente, a possibilidade de convencer os eleitores de que contavam efetivamente com tal apoio, quer no plano estadual quer no federal. Se Roland Lavigne podia argumentar com sua filiação partidária e história política, Jabes Ribeiro invocava o fato de pertencer ao partido do presidente da República, aliado, por sua vez, ao PFL do governador e do senador. Tratar-se-ia, pois, de reeditar, no plano municipal, a aliança que vencera as eleições presidenciais de 1994 e 1998. No dia 3 de outubro, Jabes Ribeiro elege-se, pela terceira vez, prefeito de Ilhéus, com quase 34.000 votos contra pouco mais de 27.000 de Roland Lavigne.

Para grande surpresa da maior parte dos eleitores, Rúbia Carvalho obteve apenas 603 votos, não passando da terceira suplência de seu partido na Câmara de Vereadores. Derrota inicialmente interpretada por seus assessores como decorrente do fato de Rúbia, certa da vitória e, ao mesmo tempo, deprimida por não ter sido indicada candidata a vice-prefeita de Jabes, não ter realizado uma campanha eleitoral eficiente. Pouco depois, essa explicação foi acrescida de outra: após sua não-indicação para vice-prefeita, Rúbia teria tentado uma aproximação com Roland Lavigne, oferecendo-se, inclusive, para fazer denúncias de corrupção contra a administração Jabes Ribeiro, da qual havia participado. Jabes teria sabido da "traição" e tratado de dificultar, de todas as maneiras possíveis, a candidatura de Rúbia.

Logo após as eleições, comentava-se que Jabes Ribeiro estaria deixando o PSDB e se filiando ao PTB, o que era explicado seja pela necessidade de solidificar "parceria" com o governo do estado, seja como manobra para evitar o processo de expulsão que o PSDB certamente moveria contra ele devido à aliança com o grupo de Antônio C arlos Magalhães. Jabes acabou não ingressando no PTB, preferindo permanecer "sem partido" ou, como se diz às vezes em Ilhéus, "à toa”. Junto com Jabes, seu irmão, segundo candidato mais votado para a Câmara de Vereadores, também abandona o PSDB. Ambos comunicaram a decisão à população através de rádios locais, ao mesmo tempo que anunciavam que "deixavam” o PSDB para Rúbia Carvalho, que, reconhecida, agradece publicamente a herança. Roland Lavigne, por sua vez, deixa o PFL logo após as eleições e ingressa no PMDB baiano.

Todos conhecemos e, até certo ponto, compartilhamos uma espécie de senso comum político que costuma tratar situações desse tipo a partir de uma abordagem característica. Habituados a noções como "partidos", 
"programas", "ideologias", somos levados a recorrer a modelos puramente negativos que costumam sustentar que instituições centrais nas democracias ocidentais apresentariam, no Brasil, um caráter flutuante, incerto e duvidoso. Assim, os partidos políticos brasileiros não teriam a consistência ideológica e programática que os caracterizaria nas democracias mais tradicionais e consolidadas. Do mesmo modo, a constante e irregular circulação de políticos entre partidos aparentemente distintos, os inesperados realinhamentos de alianças e lealdades, as flutuações ideológicas e mudanças programáticas seriam tributários do caráter incipiente da democracia brasileira, onde os partidos ainda não estariam bem enraizados, de forma que posicionamentos e ideologias permaneceriam ao sabor de idiossincrasias e conveniências mais ou menos pessoais. Se tivermos alguma inclinação pela antropologia, podemos acrescentar a isso algumas características de nossa "cultura", que tornariam difícil o estabelecimento, entre nós, de sistemas e ideais derivados da modernidade individualista e universalista.

Se essas perspectivas - uma mais "otimista", que supõe que o tempo e algumas reformas farão com que a verdadeira democracia aqui se implante; outra mais "pessimista", que presume que as resistências a vencer estão enraizadas nessa espécie de segunda natureza em que a "cultura" se converteu - são capazes, de fato, de dar conta da realidade em alguma parte é uma questão que certamente não será abordada aqui. Basta constatar, por ora, que boa parte dos pesquisadores que trabalham com a política em sociedades como a brasileira tende, por bons ou maus motivos, a buscar, para algumas noções mais “ clássicas”, substitutos empíricos e teóricos aparentemente mais adequados à realidade estudada.

Assim, para ficarmos no caso dos partidos, parece necessário reconhecer que, por mais que a instituição faça parte da legislação e da ideologia oficiais, ela nunca pareceu corresponder a uma categoria, ou a uma unidade, realmente eficaz para dar conta do efetivamente observado. Que se concentre a análise na demonstração das razões dessa fraqueza partidária, ou que se a desvie na direção de unidades e noções tidas como mais explicativas, é aqui secundário. Não é casual, portanto, que inúmeros analistas tenham proposto outras unidades de análise para a política brasileira, e a introdução da noção de "facção" no lugar da de "partido" é um bom exemplo dessa situação. De fato, se entendermos "facção" como algo distinto dos "grupos corporados [...] (quase-grupos, grupos diádicos não corporados, etc.)" - como "unidades de conflito, cujos membros são arregimentados por um líder com base em princípios variados", esses conflitos podendo ser "considerados políticos (envolvendo o 
uso do poder público)" (Palmeira 1996:54, nota 5) —, parece mais razoável utilizar essa categoria no caso da política brasileira.

Ora, se a noção de "facção" representa um descentramento e se se trata aqui, como foi dito, de propor a introdução do conceito de segmentaridade, duas questões correlatas podem e devem ser levantadas. Em primeiro lugar, estaríamos, de fato, ganhando alguma coisa ao substituirmos " partido", "grupo de interesse" ou "facção" pela noção de "grupo segmentar" ? Segundo, seria essa substituição legítima? Ou seja, as unidades e processos efetivamente relevantes no funcionamento político de nossa sociedade seriam realmente da mesma natureza que os observáveis nas chamadas sociedades segmentares?

\section{Segmentaridade 4}

Como se sabe, foram antropólogos britânicos estudando "sistemas políticos africanos" sem Estado, nas décadas de 30 e 40, que introduziram a noção de segmentaridade no pensamento antropológico. De modo muito sucinto, a idéia central é que, na ausência do Estado, outras instituições desempenhariam as funções próprias a ele. Rebatia-se, assim, na sincronia a célebre oposição diacrônica evolucionista, que opunha as sociedades baseadas no status àquelas centradas no contrato: entre ambas se situariam justamente as "sociedades segmentares", onde as linhagens fariam uma espécie de mediação entre o "sangue" e o "território". Ora, ao tentarem estabelecer a existência de uma forma específica de organização que não se confundisse nem com o parentesco nem com o Estado, Evans-Pritchard e Fortes (1940:5-7) acabaram por legar à teoria da segmentaridade dois fantasmas teóricos gêmeos, dos quais, de certo modo, jamais conseguimos nos livrar: um morfologismo - já que se tratava de determinar um modo específico de organização social (as linhagens segmentares) - e um tipologismo - já que essa forma de organização poderia ser distinguida de outras.

Por outro lado, desde 1940, não foram poucas as tentativas de exorcizar esses fantasmas. O próprio Evans-Pritchard sempre oscilou entre enraizar a segmentaridade na organização social Nuer propriamente dita, ou fazer com que essa organização dependesse de um " princípio de segmentação", que permearia os diversos níveis organizacionais da sociedade nuer (ver, esp., Evans-Pritchard 1978:264). Foi essa ênfase nos "valores” que permitiu a Dumont (1968; 1970:70-108) estabelecer uma espécie de oposição segmentar entre os dois criadores da teoria da segmentari- 
dade: a atenção de Evans-Pritchard aos princípios ideológicos e mentais que comandariam a organização social deveria ser contrastada com o enfoque de Fortes, quase exclusivamente sociológico e centrado nos " grupos corporados" (ver, esp., Fortes 1953:25-31). E se Dumont (1970:108) tem certa razão em lamentar que o desenvolvimento da antropologia social britânica tenha privilegiado a versão sociologizante (e, para ele, substancialista e individualista) da teoria da segmentaridade, seria preciso talvez observar que a visão de Fortes não é assim tão simples. Mesmo o texto de 1953 sugere que a segmentaridade tale seria o resultado da existência de um " princípio segmentar" difuso por toda a sociedade (Fortes 1953:29). E já em sua monografia, Fortes (1945:27) insistia no que denominava "técnica de contraposição" , característica de um certo " relativismo” e de um "pensamento segmentar" (Fortes 1945:21).

Muitíssima tinta correu, de 1940 até hoje, em torno da questão da segmentaridade, e meu objetivo aqui não é, nem de longe, entrar nesse debate ou mesmo resumi-lo. Limitar-me-ei a assinalar alguns momentos e alguns pontos da discussão, cruciais para a superação desse dualismo congênito entre organização social e representação mental, e para o exorcismo dos dois fantasmas que insistem em assombrar a segmentaridade, a morfologia e a tipologia.

Já em 1950, no segundo livro de sua trilogia sobre os Nuer, EvansPritchard tratou de transpor o princípio de segmentaridade do plano da estrutura social para a "religião nuer" . Transposição que possibilitaria a superação da antinomia entre organização social e representação, mas que Evans-Pritchard não parece ter levado às últimas conseqüências: o livro acabou sendo lido como mais uma reafirmação do pressuposto da determinação sociológica das representações que a antropologia britânica havia herdado de Durkheim - e isso a despeito de o autor insistir no contrário (Evans-Pritchard 1950:115, 117-122, 143, 319-322).

Cerca de dez anos mais tarde, um aluno de Evans-Pritchard trataria de reajustar a aplicação do conceito de segmentaridade ao estudo da religião. Ao analisar a religião dinka, Lienhardt evitou explicitamente sustentar que o panteão espiritual do grupo apresentasse um aspecto segmentar como conseqüência da estrutura igualmente segmentar de suas linhagens. Lienhardt afirma, ao contrário, que é a existência de um tipo particular de "experiência” entre os Dinka que confere seja a suas linhagens, seja à sua religião, uma forma segmentar. Desse modo, as noções algo abstratas de " princípio" ou "valor" de Evans-Pritchard parecem ganhar maior concretude: o ponto crucial é tratar o mundo dos homens, o dos deuses e o da natureza como uma só coisa (a sociedade dinka é uma 
"sociedade doméstica total de homens e animais") (Lienhardt 1961:25; ver, também, Goldman 1999).

Em um artigo publicado pouco antes de seu livro sobre religião, Lienhardt constatara que a representação dinka de suas próprias linhagens diferia consideravelmente do modelo nuer, já que os Dinka " pensam em termos de associação de linhagens, ligadas umas às outras de várias maneiras" (Lienhardt 1958:128), e não a partir de um princípio agnático único e totalizador. Mais que isso, e em lugar de simplesmente acrescentar mais um "tipo" às tipologias existentes, Lienhardt propõe "investigações adicionais sobre os aspectos funcionais, mais que sobre os apenas morfológicos, da segmentação política" (Lienhardt 1958: 131), lembrando que a segmentação possui "um aspecto funcional”. Além de problematizar as distinções entre organização e representação, e estrutura e função, Lienhardt também embaralha a clássica questão acerca do grau de materialidade da segmentaridade - princípio ideal ou forma efetiva de comportamento - , sustentando que a segmentaridade dinka seria, antes de tudo, uma teoria, no sentido forte do termo: uma "teoria política dinka" que serviria, simultaneamente, para explicar e orientar a " prática política" dessa sociedade (Lienhardt 1958: 106, 114).

$\mathrm{O}$ artigo de Lienhardt foi publicado originalmente em uma coletânea (Middleton e Tait 1958:VI) que pretendia ser a "sucessora de African Political Systems". A "Introdução" do livro apresenta uma importante diferenciação entre "processo" e "morfologia", que conduz a uma distinção capital entre "fissão" e "segmentação" (Middleton e Tait 1958:7-8), termos que Evans-Pritchard utilizava como sinônimos. Se a "fissão" representa uma efetiva separação de grupos (ou seja, um grupo se converte em dois ou mais), a "segmentação" é um processo reversível, e o que é apenas um grupo em determinado nível segmentar se divide em dois em outro, sem deixar de ser um no anterior. Curioso é observar que a distinção não é estendida para o processo de fusão, o qual, evidentemente, é tão distinto da agregação segmentar quanto a fissão o é da segmentação (a reunião definitiva de dois ou mais grupos em um não é a mesma coisa que uma agregação segmentar, sempre relativa e contextual). Finalmente, ao enfatizarem uma abordagem processual, Middleton e Tait demonstram que a noção de segmentaridade proposta por Evans-Pritchard e Fortes - sem importar o que eles mesmos diziam a respeito (cf. Fortes 1945: XII) - não deve ser confundida com a noção durkheimiana de sociedade segmentar (que propõem denominar "segmental") (Middleton e Tait 1958:8, nota 1). Nesse caso, trata-se de uma concepção puramente morfológica, a mera justaposição de segmentos equivalentes, sem nenhuma 
referência ao processo funcional de sua reunião e separação relativas e contínuas.

Por outro lado, e apesar de toda a ênfase no processo em detrimento da morfologia, Tribes without Rulers é anunciado desde o início como uma crítica à tipologia dos sistemas políticos proposta em African Political Systems: contra a famosa distinção entre sociedades do "G rupo A" (com "governo") e do "G rupo B" (sem "governo") - que se subdivide em um sistema ternário: sociedades baseadas no parentesco, sociedades de linhagem e sociedades com Estado (Evans-Pritchard e Fortes 1940:57) - , propõe-se uma nova tipologia, que divide as sociedades de linhagem em três subtipos: "piramidal", "múltipla inclusão", " múltipla inclusão associada” (Middleton e Tait 1958:12-14). Da mesma forma, alguns anos mais tarde, Southall (1965:126-128) apresenta uma nova " crítica da tipologia dos Estados e sistemas políticos”, propondo uma tipologia ternária: sociedade sem Estado; Estado segmentar e Estado unitário. Como se vê, a questão morfológica tende a reaparecer todas as vezes que um esforço tipológico é colocado no centro do trabalho.

Em 1956, M. G. Smith já havia arriscado uma abordagem mais puramente processualista e política dos sistemas segmentares. O ponto de partida é a hipótese de que a teoria dos sistemas de linhagens segmentares estaria baseada em uma articulação incerta de dois conceitos heterogêneos: poder e segmentação (Smith 1956:43). Se o primeiro é um conceito "substantivo", o segundo seria puramente formal, adquirindo sentido apenas quando aplicado a um conteúdo qualquer, " células da biologia ou relações políticas das linhagens” (Smith 1956:44). Ao mesmo tempo, Smith postula um caráter intrinsecamente segmentar para a ação política, na medida em que esta é definida como uma "competição pelo poder" (Smith 1956:48-49) que engendra necessariamente a divisão, ou seja, segmentos: "esses dados mostram que relações políticas e segmentação são sinônimos, o caráter corporado dos grupos emerge no contexto de relações políticas segmentares" (Smith 1956:64). Nesse sentido, a segmentação seria universal, e a tarefa do analista, distinguir os conteúdos que em diferentes sociedades seriam trabalhados pelos processos de segmentação. É aqui que Smith hesita, sugerindo, por um lado, que nas sociedades de linhagem o parentesco ou a descendência seriam esse conteúdo trabalhado pela segmentaridade; e, por outro, que ambos seriam apenas a dimensão ideológica das reais relações de poder. Tudo se passa, pois, como se a política (entendida como "competição pelo poder") fosse um dado universal existente em si mesmo, e que, em cada sociedade, receberia uma vestimenta ideológica distinta: "a linhagem é uma concep- 
ção ideológica do caráter do governo em algumas sociedades, assim como a nação, a classe, ou o partido o é em outras" (Smith 1956:64).

É bem provável, pois, que Dumont (1968:IX-XII) esteja certo em considerar essa universalização e substantivação do político o resultado de um etnocentrismo individualista, incapaz de captar as outras sociedades de seu próprio ponto de vista. Ele talvez também tenha razão em propor uma perspectiva radicalmente inversa, que se limite a reconhecer as "funções políticas" das linhagens, negando, contudo, a existência de um sistema político autônomo em sociedades como a nuer (Dumont 1968:XIIXIII; 1970:91, 94). Seria preciso reconhecer, entretanto, que o enfoque de Smith (1956:41), propondo a universalidade do "caráter contrapontístico" das relações de poder, poderia ter permitido superar tanto o morfologismo quanto o tipologismo. Se ele não o faz é, em primeiro lugar, porque a idéia da segmentação como forma, da política como conteúdo e do parentesco como ideologia, permanece tributária do que Deleuze e G uattari (1980:457) denominam "modelo hilemórfico", que implica, simultaneamente, uma forma organizadora para a matéria e uma matéria preparada para a forma, ou seja, uma indefensável exterioridade entre ambas. É essa exterioridade que acaba conduzindo a uma simples substituição da dicotomia entre sociedades com Estado e sociedades de linhagem por um continuum, oscilando entre um tipo ideal de sociedade totalmente unificado e um outro, igualmente ideal, de segmentaridade absoluta (Smith 1956:77). Ora, substituir uma tipologia descontínua por uma contínua não parece um ganho teórico ou metodológico dos mais consideráveis, e se Smith, em vez de aplicar os conceitos da ciência política tradicional desenvolvidos para falar do Estado - às sociedades de linhagem, tivesse feito o contrário, creio que os resultados de sua discussão seriam mais interessantes. Por outro lado, não há dúvida de que seu universalismo político permite insights potencialmente produtivos, como a percepção da semelhança entre linhagens e partidos políticos - ainda que Smith sustente, estranhamente, que, neste último caso, "os segmentos mobilizados se dissolvem na medida em que passam pelas cabines eleitorais" (Smith 1956:55).

Na primeira metade da década de 60 , a teoria da segmentaridade viria a sofrer ataques diretos do neo-evolucionismo (Sahlins 1961) e, principalmente, da chamada crítica processualista às teorias dos sistemas políticos, que tinha justamente nos africanistas da década de 40 um de seus alvos preferidos (ver Swartz, Turner e Tuden 1966; Swartz 1967). Essa crítica, como se sabe, insiste no suposto descompasso entre modelos ideais, expressos eventualmente em termos de segmentaridade, e os com- 
portamentos efetivamente observáveis pelos antropólogos 5 . Assim, no volume organizado por Swartz et alii, Nicholas (1966:50-51) sugere que as clivagens e alianças idealmente previstas em um sistema segmentar qualquer não passam de idealizações ou racionalizações ideológicas, que, em hipótese alguma, correspondem ao que realmente ocorre. O problema é que ao propor a substituição metodológica da noção de segmento ou grupo pela de facção, Nicholas não pode evitar a armadilha que costuma espreitar todas as críticas processualistas das teorias dos sistemas políticos: o transacionalismo e o individualismo (ver Goldman e Palmeira 1996:3; Kuper 1988:88).

Uma crítica de outra natureza, também elaborada a partir do início da década de 60, apresenta caráter mais etnográfico - no sentido de que trata de avaliar a aplicabilidade das noções desenvolvidas no estudo de sociedades africanas na análise de grupos localizados em outras regiões. Assim, em texto ao mesmo tempo de balanço e programático, Barnes (1962:5) fala de " miragem africana na Nova Guiné" e insiste nas diferenças, supostamente objetivas, entre as duas áreas etnográficas (ver Kuper 1988:88-91). Anos mais tarde, esse mesmo tipo de elaboração seria desenvolvido em relação às terras baixas da América do Sul (cf. OveringKaplan 1977; Seeger et alii 1979). Se esse procedimento comporta, sem dúvida, alguns riscos - converter tipologias regionais em tipologias mundiais e, como reconhece o próprio Barnes (1962:5), comparar " modelos" (africanos) com "realidades" (Nova G uiné) -, é inegável que, se bem conduzido, pode ter rendimento analítico muito elevado, como comprovam a etnografia e antropologia recentes da Nova Guiné e da América do Sul. Assim, é o que observa na Nova Guiné que permite a Barnes levar mais longe a distinção, estabelecida, como vimos acima, por Middleton e Tait, entre fissão e fusão (relativas), por um lado, e separação e reunião (absolutas), por outro: se a segmentação é "crônica" na África - inscrita na própria dinâmica do sistema de linhagens - , ela parece ser "catastrófica" na Nova Guiné - ou seja, irrompe estatisticamente no ciclo de desenvolvimento do grupo (Barnes 1962:8-9). E, se essa distinção contribui decisivamente para separar segmentação e linhagem, veremos adiante como contornar o risco tipológico que ela evidentemente ainda comporta.

Se, desde 1949, o próprio Evans-Pritchard (1949) já havia iniciado a transposição do modelo das linhagens segmentares para o que, muito grosseiramente, poderíamos chamar de mundo árabe, é também ao longo da década de 60 que proliferarão as tentativas, ortodoxas ou críticas, nessa direção (ver G ellner 1969; Peters 1959; 1967). Salzman (1978:54) 
demonstra que o ponto-chave dessas abordagens consistia, mais uma vez, na suposta discrepância entre o modelo ideal ou ideológico das linhagens segmentares e os comportamentos reais dos agentes sociais. O problema é que aquilo que talvez seja uma constatação efetiva levanta um problema de difícil solução: " mas por que os beduínos repetem as injunções da teoria das linhagens? [...] Os beduínos não perceberiam, então, que muitos de seus atos e alianças discordam de sua ideologia?" (Salzman 1978:55). O autor sugere que seria preciso encarar a "oposição complementar" (que está na base da segmentaridade), simultaneamente, como um modelo "da" e "para a" ação. Do primeiro ponto de vista, a ideologia pode perfeitamente discordar do que "realmente" ocorre, o que, sem dúvida, é pensado ou explicado pelos agentes como " exceções baseadas em circunstâncias não usuais e contingentes” (Salzman 1978:53-55); do segundo ponto de vista, o princípio de segmentação funciona não apenas suscitando determinadas ações, mas também impedindo outras, dando sentido a todas, e fornecendo uma espécie de "estrutura social de reserva" apta a oferecer alternativas em situações incomuns provocadas por mudanças históricas ou por qualquer tipo de eventualidade (Salzman 1978:66-69). A ideologia não é, certamente, o único fator determinante do comportamento, mas ela desempenha um papel fundamental, e cabe ao analista estabelecer, em cada caso, o peso relativo e a eficácia própria dos princípios "ideais". Isso significa, creio, ser preciso complexificar o conhecido axioma que diz que a segmentaridade "depende do contexto"; isto é evidente, mas "contexto" não deveria ser entendido de modo formalista, envolvendo apenas os níveis estruturais componentes do sistema segmentar (como faz Dumont, por exemplo), mas no sentido de "contexto de situação" (Malinowski 1972:303-304) ou "contexto de realidade cultural” (context of cultural reality) (Malinowski 1935:257-258), que inclui a necessidade de contextualizar pragmaticamente o que se observa na situação em que os princípios são acionados ou considerados para a ação.

Nessa mesma direção, Meeker (1979:11-12) abre seu livro sobre literatura e violência na Arábia do Norte, evocando, significativamente, o descrédito em que teria caído a "teoria segmentar" e, ao mesmo tempo, afirmando que, apesar disso, seria preciso reconhecer que essa teoria levanta "uma questão central sobre o caráter dessas sociedades [do Oriente Médio]". Se Meeker reconhece, então, o esgotamento da teoria da segmentaridade no que diz respeito à descrição de alianças ou processos sociais empíricos, ele insiste, por outro lado, na questão levantada por Salzman, acerca das razões para a permanência de um modelo consciente na aparência tão clara e continuamente desmentido pelos fatos 
(Meeker 1979:14). A solução do paradoxo envolveria a transferência da noção de segmentaridade do plano sociológico propriamente dito para aquele de uma "linguagem política" (Meeker 1979:14), onde ela apareceria " como uma espécie de construção teórica modelada como resposta para um problema político” (Meeker 1979:185, 188).

Já em 1986, um artigo de Dresch sobre o Iêmen resume bem o ponto alcançado por quase meio século de debates em torno da teoria da segmentaridade, sustentando que se a "teoria da linhagem" deve, de fato, ser descartada, o mesmo não ocorre com a noção de segmentação: "A teoria da linhagem e a segmentação não são a mesma coisa; de fato, elas representam dois tipos diferentes de antropologia. O primeiro trata de seqüências de eventos no plano da observação (e em particular da aparência dos grupos), enquanto o segundo trata de relações formais que caracterizam os tipos de evento possíveis" (Dresch 1986:309).

É claro que esse deslocamento poderia ser interpretado como uma simples e definitiva "culturalização" da noção de segmentaridade. Há algo mais em jogo, contudo. Ao constatar, mais uma vez, que o problema mais geral das críticas da teoria da linhagem (que se arvoram, imediata e equivocadamente, em críticas da noção de segmentação) é resvalar para o transacionalismo, Dresch (1986:310) propõe que nos livremos dessa modalidade de individualismo metodológico sem que caiamos, necessariamente, em algum tipo de sociologismo rigoroso. Assim, se a ênfase na ação individual parece ter derivado, ao menos em parte, de uma compreensível reação aos "excessos da teoria da linhagem” (Dresch 1986:319), é inútil simplesmente retornar ao determinismo sociológico, mas é preciso igualmente reconhecer que essa reação individualista não foi capaz de desenvolver uma concepção suficientemente complexa dos atores sociais. No caso etnográfico analisado pelo próprio Dresch, seria preciso, por exemplo, reconhecer que os próprios atores são atravessados pela segmentaridade: "o próprio ator [...] é constituído pela posse da honra, que é, em si mesma, como vimos, uma qualidade segmentar" (Dresch 1986:319). Do mesmo modo, Dresch sugere que o "território" a ser protegido pela ação segmentar não deve ser confundido com uma simples área geográfica, mas como uma espécie de qualidade que envolve tudo o que está ligado ao grupo (Dresch 1986:311). Ao mesmo tempo, a própria noção de "grupo" não é inteiramente empírica: "não há necessidade, contudo, de confundir os grupos com os conjuntos em nome dos quais eles agem" (Dresch 1986:318, 313-314).

Seria preciso, talvez, desenvolver essa distinção entre "atores" ou "indivíduos" e o que poderíamos chamar de "sujeitos", no sentido pleno 
do termo ${ }^{6}$. Isso fica para outra ocasião. Por ora, basta observar que em sua releitura de Os Nuer, Karp e Maynard também insistem sobre a necessidade de um modelo mais complexo para dar conta do problema da ação social. Eles acreditam, contudo, que Evans-Pritchard já havia estabelecido o caminho a seguir. Mais que isso, supõem que toda a diversidade e toda a riqueza das leituras, interpretações e críticas da questão da segmentaridade se devem, em última instância, à genialidade de Evans-Pritchard e de Os Nuer. Ora, Karp e Maynard não só demonstram a sofisticação de Evans-Pritchard em tratar a segmentaridade, simultaneamente, como princípio lógico, ideológico e sociológico, como sugerem, ousadamente, que "Os Nuer deve ser entendido como orientado para o ator [actor-oriented], mesmo se o ator é um constructo e não um indivíduo" (Karp e Maynard 1983:489). Isso significa que, ao contrário do que diz a maior parte dos críticos, "o conceito de agência humana [human agency] é central” (Karp e Maynard 1983:482), desde que reconheçamos que a "preocupação com a individualidade não é a única indicação de interesse na agência” (Karp e Maynard 1983:498) ${ }^{7}$.

É bem possível que a vertente "arabizante" dos debates em torno da segmentaridade possa ser considerada um caso particular dessa "etnografia nas margens da Europa" de que nos fala Michael Herzfeld. Ainda que o tema central de Anthropology through the Looking Glass seja a antropologia do Mediterrâneo, é forçoso reconhecer que os mecanismos teórico-ideológicos aí isolados parecem funcionar igualmente em outros area studies. A segmentaridade ocupa uma posição central na argumentação de Herzfeld: trata-se, fundamentalmente, de indagar por que as "sociedades segmentares" foram constituídas e isoladas como um "tipo", já que, desde Evans-Pritchard, se reconhece o caráter universal da segmentação (Herzfeld 1987:219, nota 6). O problema e a resposta lembram a crítica lévi-straussiana da "ilusão totêmica" : ao isolar, como tipo, as sociedades segmentares, os antropólogos acabaram fazendo o jogo de uma "ideologia de Estado", que, supondo o caráter incompleto das sociedades sem Estado (Herzfeld 1987:156), contribuiu para exorcizar e exotizar formas de vida dificilmente assimiláveis a uma certa idéia de "identidade européia" (Herzfeld 1987:165)8.

A segmentação é, portanto, universal, e isso basta para nos livrar de toda tentação tipológica: a segmentação "até recentemente era tratada como um tipo exótico em vez de um aspecto universal da vida política” (Herzfeld 1987:158). Ao mesmo tempo, o caráter "banal" do processo também costuma ser utilizado para evitar sua generalização (Herzfeld 1987:158). Na verdade, a segmentação representa um dos modelos de 
"relatividade social" acionados em qualquer sociedade: "a segmentação é o arranjo relativo das alianças políticas de acordo com critérios genealógicos, ou outros, de distância social entre grupos em disputa" (Herzfeld 1987:156, ênfases minhas). É apenas a presença de uma ideologia substancialista, típica dos Estados nacionais, que faz com que, em algumas sociedades, o grau de reconhecimento da segmentaridade seja menor do que em outras (Herzfeld 1987:159). E é a presença dessa ideologia no interior da reflexão antropológica que faz com que noções como " estrutura social" ou mesmo "organização social" acabem sendo compreendidas em uma acepção puramente morfológica, e não funcional ou processual. Assim, o reconhecimento de que não faz sentido indagar se a sociedade grega é ou não segmentar, não é obstáculo para admitir que "uma percepção segmentar das relações sociais compete com a centralização absoluta do Estado burocrático grego" (Herzfeld 1987:157). Em suma, a segmentaridade é, sobretudo, uma perspectiva, perspectiva a partir da qual também o antropólogo deve observar a realidade social se ele realmente deseja se ver livre de todo atomismo e de todo substancialismo9.

E é justamente essa perspectiva que permitiu ao próprio Herzfeld desenvolver uma sofisticadíssima análise etnográfica de uma aldeia em Creta, análise que demonstra, etnograficamente, como segmentaridade e centralidade estatal se opõem e se combinam simultaneamente (Herzfeld 1985:XI-XII): as eleições locais, por exemplo, só ganham inteligibilidade quando encaradas do ponto de vista da "política segmentar" (Herzfeld 1985:99), e mesmo as eleições nacionais só se mostram compreensíveis quando tratadas como " política segmentar estendida" (Herzfeld 1985:111).

Mas não se trata aqui - e este ponto é crucial - de simplesmente transpor tipologias que funcionavam entre sociedades para um plano intra-social qualquer. Ou seja, não se trata de pressupor que, no interior de sociedades estatais, o Estado funcione de modo inteiramente centralizado e pequenas aldeias, grandes famílias ou quaisquer outras unidades obedeçam a princípios segmentares. Ainda que a estrutura segmentar do Estado seja em geral "dissimulada”, ela existe; ao mesmo tempo, unidades claramente segmentares são continuamente cooptadas pelo aparelho de Estado, passando a obedecer a uma lógica da centralização (Herzfeld 1992a: 102-104). Entre segmentaridade e Estado as relações são de oposição e de composição, e se o " caráter necessariamente segmentar de, virtualmente, qualquer Estado-nação" (Herzfeld 1992b:63) tende a ser desconsiderado pelos antropólogos, é preciso reconhecer que "a segmentação permanece - ao menos conceitualmente - um componente paradoxalmente necessário do nacionalismo estatal" (Herzfeld 1992a: 103). 
Resumamos, então, os deslocamentos necessários a fim de que o conceito de segmentaridade possa ser legitimamente generalizado. Ou antes, indaguemos acerca das transformações necessárias para garantir a capacidade de migração do conceito. Em primeiro lugar, trata-se de recusar a falsa dicotomia entre "ideologia" e "ação" (ou princípio ideal e organização real, ou como se quiser denominar). Se aceitarmos a hipótese de Lienhardt, e encararmos a segmentaridade como uma "teoria política", seremos capazes de compreender que ela informa e dá sentido à ação sem que tenha que corresponder ponto por ponto ao que agentes e antropólogos crêem observar empiricamente. Nesse sentido, vale lembrar, com Jeanne Favret (1966:110), que "uma disposição para a segmentação" é mais importante que a segmentação propriamente dita, e que um sistema segmentar parece repousar menos sobre a "oposição dos segmentos" do que "sobre a repartição das oposições sobre um certo número de níveis ou de encaixamentos ordenados uns em relação aos outros” (Favret 1966: 109).

Em segundo lugar, é estritamente necessário libertar o conceito de seu viés sociologizante, e repetir que a segmentaridade não se confunde com um determinado tipo de sociedade ou mesmo com as linhagens. Isso significa, também, que a segmentação pode ser uma propriedade dos sistemas simbólicos em geral e aparecer em planos tão distintos quanto a organização social, as variantes de textos ou as representações da história (Herzfeld 1992b:64; 1991:55).

Ora, liberar a segmentaridade desse viés sociologizante significa igualmente liberá-la do "tipologismo" - no caso, da "grande divisão" que aprisiona o conceito, a oposição entre sistemas segmentares e sistemas estatais. Como vimos, os segundos são tão segmentares quanto os primeiros, ao menos a partir do momento em que passamos a nos interessar mais pelos processos e funções ou funcionamentos do que pelas formas. Nesse sentido, esse movimento faz com que nos afastemos, também, do "morfologismo", o segundo grande fantasma que vimos espreitar a teoria da segmentaridade.

Esses fantasmas estariam assim, de fato, definitivamente exorcizados? Não tenderiam a reaparecer cada vez que procuramos fazer distinções ou caracterizar formações? Creio que aqui talvez seja preciso um passo suplementar. Nas poucas páginas que escreveram sobre a questão da segmentaridade, Deleuze e Guattari levantam uma curiosa questão, que, todavia, deveria estar bem no centro de qualquer investigação antropológica das sociedades "complexas": " por que retornar aos primitivos, uma vez que se trata da nossa vida?” Partindo da noção de segmentaridade exatamente como foi proposta na década de 40 pelos africanistas 
britânicos (ou seja, para dar conta de sociedades "sem Estado"), eles procedem mediante ampliações sucessivas do alcance do conceito. Em primeiro lugar, distinguem três modalidades de segmentaridade (Deleuze e Guattari 1980:254): binárias (de gênero, classe, idade: assim, em Ilhéus, a distinção entre brancos e negros, por exemplo), circulares (do indivíduo à humanidade: o bairro da Conquista, a cidade de Ilhéus, a região do cacau, a Bahia, o Brasil...) e lineares (ligadas a "processos" ou "episódios" concomitantes ou sucessivos: a família, o candomblé, o bloco, o trabalho.... ${ }^{10}$. Em seguida, em uma manobra apenas provisória, tratam de distinguir uma segmentaridade "primitiva" e uma "de Estado" : se no primeiro caso subsiste uma "certa flexibilidade", no segundo temos uma "segmentaridade dura" (Deleuze e Guattari 1980:255). E se a "segmentaridade primitiva" é flexível, isto se deve ao fato de que os diversos centros de cada domínio de segmentação (território, parentesco, idade...) jamais coincidem - e o melhor exemplo disso é a impossibilidade de adequar completamente genealogia e território, com a qual se chocaram quase todos os que trabalharam com a segmentaridade; por outro lado, o Estado deve ser concebido exatamente como espaço de "ressonância" de todas as segmentações:

“ [...] a segmentaridade torna-se dura, na medida em que todos os centros ressoam [...]. O Estado central não se constitui pela abolição de uma segmentaridade circular, mas por concentricidade dos círculos distintos ou por uma ressonância dos centros [...]. As sociedades com Estado comportam-se como aparelhos de ressonância, elas organizam a ressonância, enquanto as primitivas a inibem" (Deleuze e Guattari 1980:257).

Em suma, " a vida moderna não destituiu a segmentaridade [...], ao contrário, a endureceu singularmente” (Deleuze e Guattari 1980:256). É somente a "caixa de ressonância" do Estado que pode fazer com que divisões binárias sejam continuamente reproduzidas, que os diferentes círculos que a todos envolvem pareçam ter apenas um centro, e que as diferentes atividades ou instituições com que todos estamos envolvidos tendam para uma forma única ou uma unidade transcendente. Não se trata aqui, contudo - e o ponto é central -, de supor uma nova tipologia: não há distinção empírica possível entre as segmentaridades flexível e dura; elas estão sempre juntas, interpenetrando-se e transformando uma à outra em todas as partes (Deleuze e Guattari 1980:260-261). 


\section{Política}

Parece-me, pois, que a resposta à primeira questão levantada anteriormente (sobre a legitimidade da aplicação da noção de segmentaridade à análise da "grande política" de sociedades de Estado) deve ser positiva - ao menos se compreendermos a noção do modo aqui proposto. A segunda questão (acerca dos ganhos efetivos representados pela introdução da idéia de segmentaridade) precisa, agora, ser respondida.

Comecemos tentando refrasear a história eleitoral de Ilhéus nos últimos 25 anos na chave da segmentaridade. O bipartidarismo do regime militar, com suas sublegendas tentando fazer com que aquilo que é disputa em um plano não ameace o que deve ser unidade em outro, é um exemplo suficientemente óbvio para dispensar comentários adicionais. Mais concretamente, lembremos que Jabes Ribeiro aparece na vida política como parte de um segmento que é um desmembramento de outro, comandado por Antônio Olímpio (que, evidentemente, também constituiu seu segmento ao desmembrá-lo de um anterior, e assim por diante). Jabes mostrou-se suficientemente forte para constituir seu próprio segmento, do qual João Lírio poderia ser um dos ramos. Este, contudo, e ao contrário de Jabes, não se mostrou capaz de estabelecer sua própria linha de segmentação e acabou desaparecendo do cenário político. Jabes, por sua vez, é derrotado em 1992, justamente por aquele de quem, em certo sentido, "descendia" 11. Mas isso só se tornou possível porque Antônio Olímpio, utilizando as propriedades rizomáticas da segmentaridade, já tratara de articular e aliar seu próprio segmento a outro, mais amplo, comandado por Antônio Carlos Magalhães. Ora, é justamente deste que provém Roland Lavigne, derrotado por Jabes Ribeiro em 1996 e 2000 com a diferença que, em 2000, tanto Roland quanto Jabes proclamaram sua ligação (de "filiação" ou de "aliança") com o então senador Antônio Carlos Magalhães e com o presidente da República.

Percebemos, assim, que o que é oposição em um plano pode perfeitamente ser conjunção em outro. Novamente, o caso das sublegendas é óbvio demais. Também mais ou menos óbvio é o fato de que opostos no plano municipal, Jabes e Roland podem se reencontrar no estadual, com Antônio Carlos Magalhães, e no nacional, com Fernando Henrique Cardoso: "territorialidade" e "descendência" articulam-se para permitir alianças e oposições. Menos óbvia, contudo, é a tendência dos " políticos" a se conjugarem todas as vezes que sua existência ou seu mundo parecem estar sob ameaça. É o que pode ser observado quando políticos de todas as tendências põem de lado suas divergências em nome, por 
exemplo, da defesa da democracia (posta em perigo por um golpe de Estado ou por um movimento social), da crítica ao baixo nível de participação política do povo, ou para rechaçar acusações genéricas contra a "classe política" (o que ficou, significativamente, conhecido como "corporativismo") ${ }^{12}$.

Em segundo lugar, penso que a noção de segmentaridade permite uma melhor compreensão das movimentações políticas e dos políticos mudanças de partidos, incongruências programáticas... - , tratando-as como efeitos do funcionamento de um sistema dotado de um certo tipo de estruturação dinâmica. Esse deslocamento teórico poderia evitar a tendência a explicar esse tipo de fenômeno em termos puramente negativos (falta de experiência democrática, juventude dos partidos, ausência de legislação adequada...) ou individualistas (cálculo, interesse, manipulação... - processos que, certamente, existem, mas que só podem funcionar nos quadros de um sistema mais amplo que cabe ao analista descrever).

Em terceiro lugar, como foi avançado, a noção de segmentaridade pode e deve ser aplicada a outros planos além do sociológico em sentido estrito. Assim, as narrativas dos eventos aqui analisados, inclusive a minha, seguem linhas de segmentação que se articulam com a dimensão sociopolítica. Os "mesmos" eventos que relatei, quando narrados por outros agentes, aparecem sob uma luz bastante diferente. Enquanto um sociólogo (G asparetto 1993) explica, por exemplo, o resultado das eleições de 1992 em Ilhéus como derivando de uma desaprovação ao governo municipal e da falta de aliança de Jabes Ribeiro com as esquerdas (que obtiveram cerca de 8.400 votos), o movimento negro é unânime em atribuir a vitória de Antônio Olímpio ao fato de este movimento ter sido cooptado para sua campanha, acreditando nas promessas de construção de um "centro afro-cultural" formuladas pelo candidato e por seu vice, ele próprio negro (ver G oldman 2000) ${ }^{13}$. Da mesma forma, a história de Ilhéus e da região é narrada de diferentes maneiras: enfatizando as populações indígenas, os descendentes de escravos, os migrantes sergipanos, os imigrantes estrangeiros, e assim por diante ${ }^{14}$.

Se a noção de segmentaridade pode ajudar a compreender o funcionamento de nosso próprio sistema político, não parece menos verdadeiro que a aplicação do conceito a esse sistema também deva gerar transformações no plano conceitual. Nesse sentido, é preciso observar que, ao contrário do que o caso nuer tende a fazer crer, os diferentes segmentos do sistema não se situam univocamente sobre planos uniformes do diagrama segmentar: pode ser verdadeiro que, de um ponto de vista " genealógico”, Jabes Ribeiro provenha de Antônio Olímpio (no sentido de que 
uma linhagem menor deriva de uma maior), mas isso não significa que o primeiro seja necessariamente açambarcado pelo segundo, de acordo com o modelo em que unidades de ordem inferior podem se opor entre si, mas não a uma de ordem superior. Antônio Olímpio, nesse caso, está simultaneamente na origem hierárquica de Jabes Ribeiro e de outros políticos (o que não deixa de ser lembrado, com diferentes intenções, por eleitores e adversários), e figura como unidade da mesma ordem e "ao lado" de Jabes - o que permite que eles se oponham ou se aliem. Em suma, a segmentação não está necessariamente ligada à genealogia e se a narrativa diacrônica pode aumentar a inteligibilidade da descrição, ela não é estritamente necessária ou suficiente ${ }^{15}$.

Em outros termos, se nas sociedades de linhagem o processo de segmentação parece transcorrer sobre um plano diacrônico irreversível, e se, por outro lado, o conjunto das operações de segmentação e fusão está inteiramente dado, como possibilidade, a cada instante, no caso das formações segmentares em sociedades de Estado, tudo parece se passar sobre um eixo diacrônico reversível, que permite que segmentos separados se reúnam para se dissolver mais adiante e, eventualmente, se reunir novamente.

Além disso, a "politização" da noção de segmentaridade permite perceber que nem sempre a lógica do provérbio árabe "eu contra meus irmãos; meus irmãos e eu contra meus primos; meus primos, meus irmãos e eu contra o mundo" (Salzman 1978:53; Favret 1966:108) é realmente posta em prática. Um pouco à maneira do que ocorre com as torcidas de futebol - onde é comum apoiar uma equipe mais "distante" contra uma mais " próxima" e, por isso mesmo, dotada de um maior potencial de rivalidade -, em política não é incomum que alianças que cortam o espaço segmentar sejam efetuadas. Desse modo, Rúbia Carvalho, muito mais próxima, ideológica e "genealogicamente", de Roland Lavigne, acaba se aliando a Jabes Ribeiro. Este, por sua vez, rompe com seus aliados de esquerda e aproxima-se de Antônio Carlos Magalhães e de Fernando Henrique Cardoso.

\section{Algumas conclusões}

O principal ganho metodológico, teórico e, talvez, político, obtido com a introdução de um conceito plural de segmentaridade, é, parece-me, sua capacidade de tornar inteligíveis alguns dos mecanismos através dos quais se dá a articulação entre segmentos políticos e unidades derivadas 
de outros processos de segmentação. Ao escrever sobre C reta, Herzfeld observa que:

\begin{abstract}
“ Tomemos, por exemplo, sua compreensão das relações políticas no interior do Estado-nação. O Estado burocrático endossa um modelo piramidal ou hierárquico das relações políticas. Da perspectiva dos aldeões, contudo, a relação pode, ao contrário, ser segmentar. Nesse modelo, grupos rivais de parentes unem-se na defesa de sua aldeia comum; aldeias em disputa unem-se em sua lealdade para com uma identidade regional; e regiões subordinam suas lealdades competitivas à lealdade maior comandada pela nação englobante" (Herzfeld 1985:XI).
\end{abstract}

Se a interpretação de Herzfeld pode ser correta para Creta e para a G récia, creio que no caso de Ilhéus, e talvez do Brasil, ela deva ser ligeiramente ajustada. Isto porque a descrição anterior parece supor que os aldeões cretenses pensam sua comunidade como uma espécie de pequeno Estado, e o Estado grego como o segmento mais inclusivo de um sistema segmentar. Se, do ponto de vista da segmentaridade circular, esse modelo é satisfatório, ele parece longe de esgotar todas as possibilidades. Assim, ao menos em Ilhéus, esse modelo "arborescente" ("nuer”) convive com uma segmentaridade mais linear e "rizomática” ("dinka”), onde o Estado parece ser encarado como um segmento paralelo aos demais, e o fato de ser tido como incomensuravelmente mais forte que os segmentos locais não significa necessariamente que seja encarado como totalidade englobante em qualquer ocasião.

Como demonstrou Cecilia McCallum (1996:207), esse englobamento pode ocorrer em determinadas ocasiões, como no futebol, por exemplo; mas esse "nacionalismo local" não deixa de conviver com sentimentos inteiramente negativos acerca do Estado e mesmo da nação. Isso é possível, creio, porque as duas reações se passam não apenas em níveis segmentares distintos, mas segundo diferentes formas de segmentaridade: uma circular, indo do indivíduo à nação, e outra binária ou linear, que faz com que as comemorações pelas vitórias " não neguem a hierarquia, mas simplesmente a desloquem temporariamente” (McCallum 1996:222). Nos termos do próprio Herzfeld (1992a:99, 107; 1996:26-27), trata-se aqui de mecanismos semiótico-políticos que consistem em converter " relações indéxicas” locais, ou propriamente "sociais” (que envolvem conhecimento direto mútuo e preservam um alto grau de contextualidade), em relações “icônicas” ou "culturais" (que tendem a literalizar os símbolos, desvinculando-os de seu contexto). 
É por isso que o fascinante e crucial processo de "conversão de símbolos étnicos em símbolos nacionais”, isolado por Peter Fry (1977:47), só teria a ganhar se o encarássemos do ponto de vista da segmentaridade. Não parece que a feijoada, o candomblé ou o samba sejam jamais alçados definitivamente da primeira para a segunda condição. Na verdade, seu valor simbólico oscila de acordo com os níveis segmentares considerados, e a questão não se reduz simplesmente a capturar o símbolo, mas tentar eliminar suas ambigüidades, fazendo com que adquira um sentido unívoco - tarefa, é claro, jamais inteiramente bem-sucedida. Não é por acaso, portanto, que, em 1973, o jornal O Estado de S. Paulo tenha podido criticar o governo paulista por este ter organizado uma grande festa pública de umbanda: enquanto o governador visava o nível segmentar mais elevado, em que a umbanda pode funcionar como representação do Brasil como um todo, o periódico mirava um nível inferior, onde elite e umbandistas só podem se opor (Fry 1977:46). Da mesma forma, o fato de as "baianas" da festa do Dois de Julho, de que fala McCallum (1997:3), aparecerem como "símbolos baianos", não significa que elas o sejam sempre e em todos os níveis segmentares: o problema do ponto de vista político é justamente fazer com que elas sejam apenas isso.

Esse mesmo tipo de deslizamento explica, creio, por que se oscila tanto entre considerar blocos afro, terreiros de candomblé e outras associações do gênero como formas de resistência ou como alvos ideais para a cooptação política (ver Morales 1991:84-89, para o Afoxé Filhos de Gandhi; Siqueira 1996:139, 141-142, para o Ilê Aiyê; C unha 1989 e 1998, para o movimento negro em geral). McCallum (1996:208) fala na existência de uma "dialética de 'hegemonia' e 'resistência', e sugere "séria atenção" na "política pessoal que denominei "resistência”" (McCallum 1997:27-28). E ela tem certamente razão de lembrar que mesmo a cooptação eleitoralmente bem-sucedida não significa captura total e que o famoso ceticismo popular para com a política bem poderia ser encarado como uma forma de resistência: "o processo eleitoral não é uma medida absoluta de hegemonia” (McCallum 1997:27).

Como vimos em Ilhéus, não há dúvida de que os distintos segmentos políticos buscam capturar e se articular com aqueles do movimento negro da cidade, que obedece igualmente a uma lógica segmentar. Generalizando, poderíamos talvez dizer que as diversas formas de segmentação que recortam não apenas os grupos afro e as camadas mais pobres da população de Ilhéus, mas a cidade como um todo, funcionam como pontos de encaixe para a grande política, ou melhor, para seus diversos segmentos. Uma família pode dividir os votos de seus membros entre 
diferentes candidatos a quem sentem dever alguma coisa, ou em quem depositam alguma esperança ou interesse, mas o político bem-sucedido é aquele que é capaz de "sobrecodificar" (Deleuze e Guattari 1972:227236) de alguma forma essa dispersão, e obter a quantidade de votos suficiente para elegê- $\mathrm{lo}^{16}$. Se um candidato tem capacidade para aproveitar a série de divisões segmentares entre os diversos blocos afro, pode impedir que estes se articulem em torno de um candidato único e, ao mesmo tempo, garantir um razoável número de votos para sua eleição. Por outro lado, os membros das organizações negras não costumam ter êxito em suas incursões diretas na política partidária: em 1988, por exemplo, o presidente do Afoxé Filhos de Gandhi conseguiu apenas 242 votos nas eleições para a Câmara Municipal de Salvador, e o do Ilê Aiyê, 781 votos (em um universo de aproximadamente 4.000 associados em cada uma das organizações) (cf. Morales 1991:86). Em Ilhéus, o movimento negro lamenta constantemente jamais ter conseguido eleger um candidato.

As organizações segmentares mantêm, pois, com o Estado (também dotado de uma estrutura segmentar) uma relação semelhante à postulada por Pierre Clastres $(1974 ; 1980)$ para a chefia indígena sul-americana: nos dois casos, trata-se, ao mesmo tempo, de uma prefiguração do Estado (já que segmentos e chefia podem funcionar como pólos de unificação e centralização), e de uma conjuração (na medida em que a chefia indígena é impotente e que as formações segmentares se desfazem e refazem ininterruptamente) ${ }^{17}$. Do ponto de vista da segmentaridade circular, os políticos parecem englobar os agentes sociais - e sente-se que é inútil se opor a eles; do ponto de vista da segmentaridade binária, surgem como seres de outra natureza (mas todos da mesma natureza, o que explica, em parte, o difuso sentimento de que "todos os políticos são iguais"), movendo-se em um mundo sobre o qual os agentes sentem não possuir nenhum poder; do ponto de vista da segmentaridade linear, fazem parte de unidades com as quais é possível estabelecer relações de aliança, mas também de oposição. Que tipo de sentimento será dominante e que relação será efetivamente estabelecida — ou seja, em qual de seus pontos o sistema se segmentará ou se recomporá —, depende do "contexto de situação".

A captura, dizem Deleuze e Guattari (1980:531-532), é a "essência interior", ou a "unidade", de todas as formações estatais, e o Estado é capaz até mesmo de imprimir sua forma aos grupos que a ele se opõem ou aos movimentos que dele tentam escapar (Herzfeld 1996:77). Se a "busca pelo segmentável" é a busca pelo “unificável" (Herzfeld 1992b:63), é porque a própria segmentaridade, ao contrário do que se costuma ima- 
ginar, não consiste na divisão de uma suposta unidade primeira em entidades discretas, mas na conversão de multiplicidades em segmentos, ou seja, em unidades simultaneamente divisíveis e unificáveis.

Nenhum pessimismo aqui: aos mecanismos de captura e conjugação respondem sempre, e incessantemente, as conexões, resistências e linhas de fuga. Ouvindo uma música do Ilê Aiyê com meus amigos de Ilhéus, mostrei-me intrigado com o verso "a liberdade parece com a linha do Equador" (que, mais tarde, eu usaria como epígrafe de um livro). Sugeri que ambas seriam imaginárias; responderam-me, primeiro, que as duas estão aí só que ninguém as vê; depois que, como a linha do Equador, a liberdade tem que ser traçada.

Recebido em 19/7/01

Aprovado em 20/8/01

Marcio G oldman é professor do Programa de Pós-G raduação em Antropologia Social (Museu Nacional, Universidade Federal do Rio de Janeiro), pesquisador do CNPq e do NuAP (Núcleo de Antropologia da Política, Pronex). É autor de Razão e Diferença. Afetividade, Racionalidade e Relativismo no Pensamento de Lévy-Bruhl (1994), Alguma Antropologia (1999) e organizador, com Moacir Palmeira, de Antropologia, Voto e Representação Política (1996). E-mail: goldman@alternex.com.br. 


\section{Notas}

* Uma primeira versão deste trabalho foi apresentada no fórum Teorias Etnográficas da Segmentaridade, coordenado por Tânia Stolze Lima e Márcio Ferreira da Silva, na XXII Reunião da Associação Brasileira de Antropologia (ABA), em julho de 2000. Agradeço aos organizadores e a todos os participantes do fórum (o texto apresentado por Antônio Rafael (Rafael 2001) foi especialmente importante para a elaboração deste trabalho). Agradeço também a Paulo Rodrigues dos Santos, meu auxiliar de pesquisa em 1996, a Thereza C ristina Cardoso Menezes, Ana Cláudia Cruz da Silva e Silvia Nogueira, que realizaram ou realizam pesquisas em Ilhéus sob minha orientação (parte do material aqui utilizado foi por eles coletada). A lista das pessoas que têm me apoiado em Ilhéus ultrapassa o espaço de que disponho. Agradeço a todos através do Dr. José Carlos Ribeiro, Raimunda Alencar e, especialmente, da família Rodrigues. Aos militantes negros de Ilhéus, em especial Marinho Rodrigues e Jaco Santana, é difícil agradecer: eles mudaram minha vida.

1 Em uma resenha de um livro recente de Agier (2000) que, infelizmente, não pude consultar, Moura (Moura e Agier 2000:373-374) aponta essa ausência (ver, também, Vianna 2001).

2 A cidade tem, hoje, cerca de 145.000 habitantes na área urbana; o município, cerca de 240.000 .

3 É curioso observar a evitação desse tema nos relatos sobre os blocos de Salvador.

4 "Dado um sistema de grupos em que os grupos A, B, C, D etc. compreendem subdivisões de primeira ordem A1, A2, A3, B1, B2, B3 etc., que, por sua vez, compreendem subdivisões de segunda ordem, A 1a, A 1b etc., B1a, B1b etc., e assim sucessivamente [...]. O sistema é chamado segmentar se as subdivisões das diversas ordens coexistem virtualmente a cada instante e só se manifestam alternativamente em situações determinadas" (Dumont 1970:73).

5 "Quero insistir que os sistemas de parentesco não possuem nenhuma 'realidade', exceto em relação à terra e à propriedade. O que os antropólogos sociais denominam estrutura de parentesco é apenas um modo de falar sobre as relações de propriedade, sobre as quais também se pode falar de outras maneiras" (Leach 1961:305; ver, também, Bourdieu 1977:58-63; Barth 1969).

6 “Infelizmente, os antropólogos, em geral, consideraram que atores com muito peso psicológico eram difíceis de manipular metodologicamente - e os teóricos da prática não são aqui exceção” (Ortner 1984:151).

7 É curioso observar que no meio dessa série de tentativas de libertação da noção de segmentaridade de sua prisão sociológica representada pelas linhagens, 
Kuper tenha realizado um balanço inteiramente negativo da "teoria da linhagem" e, por extensão, da noção de “oposição segmentar” (Kuper 1982; ver, também, Kuper 1988). E é importante assinalar que a condição da crítica radical de Kuper é a limitação da noção de segmentaridade a um plano sociológico estrito onde ela pode, aparentemente, ser mais facilmente criticada.

8 Herzfeld (1987:219-220, nota 5) relata que, entre 1979 e 1980, vários antropólogos, a maior parte da Universidade de Indiana, participaram de debates em torno da "relevância do conceito de segmentação", entre os quais estavam, além do próprio Herzfeld, Karp, Maynard, Meeker e Salzman.

9 Herzfeld desenvolve esse ponto em alguns artigos publicados em Cultural Intimacy, onde demonstra que conceitos como "etnicidade" e "identidade" correspondem a uma forma de "literalização" das relações sociais cuja essência é fundamentalmente relativa, ou seja, segmentar (ver, esp., Herzfeld 1996:75-77, 81-83, 93-95, 181, nota 8).

${ }^{10}$ É curioso que Smith (1956:57-58) só contemple a possibilidade de incluir as relações de gênero e idade no modelo da segmentaridade para afastá-la sumariamente. Tudo se passa como se só fôssemos capazes de perceber a forma piramidal ("arborescente") da estrutura segmentar. No entanto, como vimos, as linhagens dinka apresentam um aspecto muito diferente, aproximando-se do que Deleuze e G uattari denominam “rizoma” (cf. Deleuze e Guattari 1980: 46-47, 256-259). A segmentação não pode ser oposta em bloco ao Estado, não apenas porque o Estado está por ela permeado como também porque existem modalidades distintas de segmentação mesmo nas chamadas "sociedades segmentares".

${ }^{11}$ É claro que se “segmentação” pode ser aplicada em sentido “próprio” à vida política das sociedades com Estado, noções ligadas à idéia de "descendência" devem ser compreendidas em sentido apenas metafórico.

$12 \mathrm{G}$ raham observa como, no Brasil do século XIX, havia um esforço consciente para canalizar qualquer forma de protesto ou oposição para o interior da política eleitoral legal: “ o constante esforço em legislar eleições justas demonstra uma preocupação em abrir a política a homens de opiniões divergentes, que assim não se voltariam contra o regime” (G raham 1990:73).

${ }^{13}$ Não me parece que a ausência no trabalho de Gasparetto de qualquer referência ao envolvimento do movimento negro se deva a alguma particularidade da produção intelectual local: trata-se de uma tendência generalizada de subtrair dos atores socialmente não privilegiados toda a agência. Tudo se passa como uma aceitação passiva e uma espécie de duplicação da ideologia da democracia representativa, em que os únicos verdadeiros agentes são as elites e os políticos: os "eleitores" só aparecem como valores agregados em tabelas estatísticas ou como objetos de manipulação. 
${ }^{14}$ Basta uma rápida incursão pela historiografia local para nos certificarmos disso: ver, p. ex., Andrade (1996); Barbosa (1994); Adonias Filho (1976); Heine (1994); Lipiello (1996); Schaun (1999). O melhor trabalho histórico sobre a região é o de Mahony (1996). Ver, também, Mahony (1998) e Viegas (1998).

${ }^{15}$ Essa mesma dualidade de princípios é observável no caso dos blocos afro. Em Salvador, por exemplo, o Ilê Aiyê pode ser reconhecido como origem de todos os blocos sem que isto impeça que haja competição entre eles - seja nos desfiles de carnaval, seja na busca de reconhecimento, projeção e sucesso.

16 “ A sobrecodificação, esta é a operação que constitui a essência do Estado” (Deleuze e Guattari 1972:236); “ o termo sobrecodificação corresponde a uma codificação de segundo grau. Exemplo: sociedades agrárias primitivas, funcionando segundo seu próprio sistema de codificação territorializado, são sobrecodificadas por uma estrutura imperial, relativamente desterritorializada, impondo a elas sua hegemonia militar, religiosa, fiscal etc." (Guattari 1986:289).

${ }^{17} \mathrm{G}$ ellner sugeriu que a "vontade de autonomia em face de um poder central" seria um traço de unidade das tribos da África do Norte: "Divide that ye not be ruled” (Favret 1966:107); Salzman (1978:63) demonstra como a organização segmentar dos Yomut sempre funcionou como uma máquina de guerra contra o Estado persa. No plano teórico, Karp e Maynard (1983:488) sugerem que "os Nuer contribuem com um exemplo negativo para a teoria do Estado". 


\section{Referências bibliográficas}

ADONIAS FILHO. 1976. Sul da Bahia: Chão de Cacau (Uma Civilização Regional). Rio de Janeiro: Civilização Brasileira.

AGIER, Michel. 1992. “Ethnopolitique: Racisme, Statuts et Mouvements Noir à Bahia". Cahiers d'Études Africaines, XXXII(1):53-81.

. 2000. Anthropologie du Carnaval. La Ville, La Fête et I'Afrique à Bahia. Marseille: Ed. Parenthèse.

ANDRADE, Maria Palma. 1996. Ilhéus: Passado e Presente. Salvador: BDABahia.

BARBOSA, Carlos Roberto Arléo. 1994. Notícia Histórica de Ilhéus. Itabuna, BA: s/e.

BARNES, John A. 1962. “African Models in the New Guinea Highlands”. Man, 2:5-9.

BARTH, Fredrik. 1969. “Introduction”. In: F. Barth (ed.), Ethnic Groups and Boundaries. London: George Allen and Unwin. pp. 9-39.

BOURDIEU, Pierre. 1977. Outline of a Theory of Practice. Cambridge: Cambridge University Press.

CLASTRES, Pierre. 1974. La Société Contre l'État. Paris: Minuit.

_ . 1980. Recherches d'A nthropologie Politique. Paris: Minuit.

CUNHA, Olívia Gomes da. 1989. “Impressões da Festa: Blocos Afro sob o Olhar da Imprensa Baiana” . Estudos Afro-A siáticos, 16:179-183.

. 1991. C orações Rastafari. Lazer, Política e Religião em Salvador. Dissertação de Mestrado, PPGAS/Museu Nacional/UFRJ.

. 1998. "Black Movements and the 'Politics of Identity' in Brazil'. In: S. E. Alvarez, E. Dagnino e A. Escobar (eds.), Culture of Politics, Politics of
Culture. Re-Visioning Latin American Social Movements. Oxford: Westview Press. pp. 220-251.

DELEUZE, Gilles e GUATTARI, Félix. 1972. L'Anti CEdipe. Paris: Minuit.

_ . 1980. Mille Plateaux. Paris: Minuit. DRESCH, Paul. 1986. “The Significance of the Course Events Take in Segmentary Systems". American Ethnologist, 13:309-324.

DUMONT, Louis. 1968. "Préface". In: E. E. Evans-Pritchard, Les Nuer. Paris: Gallimard. pp. I-XV. . 1970. Groupes de Filiation et Alliance de $\mathrm{M}$ ariage. Introduction à Deux Théories d'A nthropologie Sociale. Paris: Gallimard.

EVANS-PRITCHARD, Edward E. 1978 [1940]. Os N uer. São Paulo: Perspectiva.

1949. The Sanusi of Cyrenaica. Oxford: Clarendon Press. . 1950. Nuer Religion. Oxford: Oxford University Press. e FORTES, Meyer. 1940. "Introduction”. In: E. E. Evans-Pritchard e M. Fortes (eds.), African Political Systems. Oxford: Oxford University Press. pp. 2-23.

FALCÓN, G ustavo. 1995. Os Coronéis do Cacau. Salvador: Ianamá.

FAVRET, Jeanne. 1966. “La Segmentarité au Maghreb”. L'Homme, VI(2): 105- 111.

FORTES, Meyer. 1945. The Dynamics of Clanship among the Tallensi. Being the First Part of an A nalysis of the Social Structure of a Trans-Volta Tribe. Oxford: Oxford University Press. . 1953. "The Structure of Unilineal Descent Groups” . American Anthropologist, 55:17-41. 
FRY, Peter. 1977. "Feijoada e Soul Food: Notas sobre a Manipulação de Símbolos Étnicos e Nacionais”. Ensaios de Opinião, 2:45-47.

GASPARETTO, Agenor. 1993. A Sucessão M unicipal no Sul da Bahia. Itabuna, BA: Sócio Estatística Pesquisa \& Consultoria Ltda.

GELLNER, Ernest. 1969. Saints of the AtIas. Chicago: University of Chicago Press.

GOLDMAN, Marcio. 1999. “A Experiência de Lienhardt: Uma Teoria Etnográfica da Religião”. Religião e Sociedade, 19(2):9-30.

. 2000. “Uma Teoria Etnográfica da Democracia. A Política do Ponto de Vista do Movimento Negro de Ilhéus, Bahia, Brasil”. Etnográfica, IV(2): 311-332.

_ _ e PALMEIRA, Moacir. 1996. "Apresentação”. In: M. Palmeira e M. Goldman (eds.), A ntropologia, Voto e Representação Política. Rio de Janeiro: Contra Capa. pp. 1-12.

GOLI, Guerreiro. 1998. “Um Mapa em Preto e Branco da Música na Bahia. Territorialização e Mestiçagem no Meio Musical de Salvador (1987/ 1997)”. In: L. Sansone e J. T. dos Santos (eds.), Ritmos em Trânsito. SócioAntropologia da M úsica Baiana. Salvador: Dynamis Editorial. pp. 97-122. GRAHAM, Richard. 1990. Patronage and Politics in Nineteenth-Century Brazil. Stanford: Stanford University Press.

GUATTARI, Félix. 1986. Les Années d'Hiver. Paris: Barrault.

HEINE, Maria Luiza. 1994. Passeio Histórico na Capitania de São J orge dos Ilhéus. São Paulo: GRD.

HERZFELD, Michael. 1985. The Poetics of M anhood: Contest and Identity in a Cretan M ountain Village. Princeton: Princeton University Press. . 1987. Anthropology through the Looking Glass. Critical Ethnography in the Margins of Europe. New York/ Cambridge: Cambridge University Press.

1991. A Place in History. Social and $\mathrm{M}$ onumental Time in a Cretan Town. Princeton: Princeton University Press.

. 1992a. The Social Production of Indifference. Exploring the Roots of Western Bureaucracy. Chicago: The University of Chicago Press.

1992b. "Segmentation and Politics in the European Nation-State: Making Sense of Political Events". In: K. Hastrup (ed.), Other Histories. London: Routledge. pp. 62-81.

. 1996. Cultural Intimacy. Social Poetics in the Nation-State. New York/ London: Routledge.

KARP, Ivan e MAYNARD, Kent. 1983.

"Reading The Nuer". Current Anthropology, 24:481-503.

KUPER, Adam. 1982. “Lineage Theory: A C ritical Retrospect”. Annual Review of Anthropology, 11:71-95.

1988. The Invention of Primitive Society. Transformations of an Illusion. London: Routledge.

LEACH, Edmund. 1961. Pul Eliya, a Village in Ceylon. Cambridge: $\mathrm{Cam}$ bridge University Press.

LIENHARDT, Godfrey. 1958. “The Western Dinka” . In: J. Middleton e D. Tait (eds.), Tribes without Rulers. Studies in African Segmentary Systems. London: Routledge \& Kegan Paul Ltd. pp. 97-135.

.1961. Divinity and Experience. The Religion of the Dinka. Oxford: The Clarendon Press.

LIMA, Ari. 1998. "O Fenômeno Timbalada: Cultura Musical Afro-Pop e Juventude Baiana Negro-Mestiça” . In: L. Sansone e J. T. dos Santos (eds.), Ritmos em Trânsito. Sócio-A ntropologia da Música Baiana. Salvador: Dynamis Editorial. pp. 161-180. 
LIPIELLO, Sergio. 1996. Ilhéus. Que Destino? Itabuna, BA: Colorpress.

MAHONY, Mary Ann. 1996. The World Cacao Made: Society, Politics, and History in Southern Bahia, Brazil, 1822- 1919. Ph.D. Thesis, Yale University.

1998. “Afro-Brazilians, Land Reform, and the Question of Social Mobility in Southern Bahia, 18801920”. In: H. Kraay (ed.), AfroBrazilian Culture and Politics. Bahia, 1790s to 1990s. New York/London: M. E. Sharpe. pp. 90-116.

MALINOWSKI, Bronislaw. 1972[1923]. “ O Problema do Significado em Linguagens Primitivas". In: C. K. Ogden e I. A. Richards (eds.), O Significado de Significado. Um Estudo da Influência da Linguagem sobre o Pensamento e sobre a Ciência do Simbolismo. Rio de Janeiro: Zahar. pp. 295-330.

1935. Coral Gardens and their Magic. A Study of the Methods of Tilling the Soil and of Agricultural Rites in the Trobriand Islands. London: George Allen \& Unwin.

MCCALlUM, Cecilia. 1996. "Resisting Brazil: Perspectives on Local Nationalism in Salvador da Bahia”. Ethnos, 61(3-4):207-230.

1997. The Redskin Within: Popular Indianism and Official Nationalism in Salvador da Bahia. Mimeo.

MEEKER, Michael. 1979. Literature and Violence in North Arabia. Cambridge: Cambridge University Press. MIDDLETON, John e TAIT, David (eds.). 1958. Tribes without Rulers. Studies in A frican Segmentary Systems. London: Routledge \& Kegan Paul Ltd.

MORALES, Anamaria. 1988. “O Afoxé Filhos de G andhi Pede Paz". In: J. J. Reis (ed.), Escravidão e Invenção da Liberdade. Estudos sobre o Negro no Brasil. São Paulo: Brasiliense. pp. 264-274.
1991. "Blocos Negros em Salvador. Reelaboração Cultural e Símbolos de Baianidade". Caderno $\mathrm{CRH}$, Suplemento:72-91.

MOURA, Milton e AGIER, Michel. 2000. "Um Debate sobre o Carnaval do Ilê Aiyê”. Afro-Ásia, 24:367-378.

NICHOLAS, Ralph W. 1966. "Segmentary Factional Political Systems”. In: M. J. Swartz, V. W. Turner e A. Tuden (eds.), Political Anthropology. Chicago: Aldine. pp. 49-59.

ORTNER, Sherry B. 1984. "Theory in Anthropology since the Sixties”. Comparative Studies in Society and History, 26(1): 126- 166.

OVERING-KAPLAN, Joanna (ed.). 1977. "Social Time and Social Space in Lowland South American Societies". Actes du XLII Congrès International des Américanistes. Paris: Société des Américanistes.

PALMEIRA, Moacir. 1996. "Política, Facções e Voto”. In: M. Palmeira e M. Goldman (eds.), A ntropologia, Voto e Representação Política. Rio de Janeiro: Contra Capa. pp. 41-56.

PETERS, Emrys L. 1959. “ The Proliferation of Segments in the Lineage of the Bedouin of Cyrenaica”. J ournal of the Royal Anthropological Institute, 90(1):29-53.

1967. "Some Structural Aspects of the Feud among the Camel-Hearding Bedouin of Cyrenaica”. A frica, 37:261-282.

RAFAEL, Antônio. 2001. "Segmentaridade e Tráfico de Drogas no Rio de Janeiro" . Alceu. Revista de Comunicação, Cultura e Política, 2(2).

RISÉRIO, Antônio. 1981. Carnaval Ijexá. Notas sobre Afoxés e Blocos do Novo Carnaval Afrobaiano. Salvador: Corrupio.

SAHLINS, Marshall. 1961. "The Segmentary Lineage: An Organization of Predatory Expansion”. In: R. Co- 
hen e J. Middleton (eds.), Comparative Political Systems. Studies in the Politics of Pre-Industrial Societies. New York: The Natural History Press. pp. 89- 119.

SALZMAN, Philip. 1978. "Does Complementary Opposition Exist?” . American A nthropologist, 80(1):53-70.

SCHAEBER, Petra. 1998. "Música Negra nos Tempos de Globalização: Produção Musical e Management da Identidade Étnica - O Caso do Olodum". In: L. Sansone e J. T. dos Santos (eds.), Ritmos em Trânsito. SócioAntropologia da Música Baiana. Salvador: Dynamis Editorial. pp. 145- 159.

SCHAUN, Maria. 1999. O Elo Perdido. Ilhéus, BA: Editus.

SEEGER, Anthony, DAMATTA, Roberto e VIVEIROS DE CASTRO, Eduardo. 1979. "A Construção da Pessoa nas Sociedades Indígenas Brasileiras”. Boletim do M useu Nacional, 32:2-19. SERRES, Michel. 1997. O que É Identidade? Mimeo.

SILVA, Ana Claudia Cruz da. 1998. A Cidadania no Ritmo do Movimento Afro-Cultural de Ilhéus. Dissertação de Mestrado, PPGAS/Museu Nacional/UFRJ.

SIQUEIRA, Maria de Lourdes. 1996. “Ancestralidade e Contemporaneidade de Organizações de Resistência Afro-Brasileira". In: T. Fischer (ed.), Gestão Contemporânea. Cidades Estratégicas e Organizações Locais. Rio de Janeiro: Fundação Getulio Vargas Editora. pp. 133-149.

SMITH, M. G. 1956. “On Segmentary Lineage Systems". J ournal of the Royal Anthropological Institute, 86(2):39-80.

SOUTHALL, Aidan. 1965. "A Critique of the Tipology of States and Political Systems". In: A. Southall (ed.), Political Systems and the Distribution of Power. London: Tavistock. pp. 113-140.

SWARTZ, Marc J. (ed.). 1967. Local Level Politics. Chicago: Aldine.

, TURNER, Victor W. e TUDEN, Arthur (eds.). 1966. Political Anthropology. Chicago: Aldine.

VALENTE, Ana Lúcia Eduardo Farah. 1986. Política e Relações Raciais: Os Negros e as Eleições Paulistas de 1982. São Paulo: USP.

VEIGA, Ericivaldo. 1998. "O Errante e Apocalíptico Muzenza”. In: L. Sansone e J. T. dos Santos (eds.), Ritmos em Trânsito. Sócio-A ntropologia da M úsica Baiana. Salvador: Dynamis Editorial. pp. 123-143.

VIANNA, Hermano. 2001. "Resenha do livro Anthropologie du Carnaval, de Michel Agier". Mana, 7(1):165-167. VIEGAS, Susana de Matos. 1998. “Índios que Não Querem Ser Índios: Etnografia Localizada e Identidades Multi-Referenciais”. Etnográfica, 2(1):91111. 


\section{Resumo}

Partindo do pressuposto de que os processos de segmentação não se opõem necessariamente àqueles ligados ao Estado, este trabalho pretende explorar a forma pela qual as divisões segmentares que recortam grupos do movimento negro de Ilhéus podem funcionar, ao mesmo tempo, como formas de resistência e como pontos de encaixe para a atuação de mecanismos dependentes de uma lógica de Estado. Trata-se de realçar tanto os processos de "captura" utilizados pelo Estado, quanto as resistências acionadas pelas formações segmentares. De um ponto de vista teórico, trata-se de demonstrar que a aplicação a nossa própria sociedade de categorias tradicionalmente desenvolvidas para dar conta de outras culturas deve deixar de ser simples metáfora ou recurso estilístico para se converter em instrumento de observação e interpretação. Para isso, é necessário que essas categorias sejam flexibilizadas e transformadas, o que não deixa de produzir efeitos também sobre a análise dessas " outras culturas".

Palavras-chave Segmentaridade, Política, Movimento Negro, Bahia

\section{Abstract}

Assuming that processes of segmentation are not necessarily opposed to those linked to the state, this article seeks to explore the ways through which the segmentary divisions characteristic of Black Movement groups in Ilhéus can function simultaneously as forms of resistance and as nodal points for mechanisms which are dependent on a state logic. It is a matter of emphasising both the processes of "capture" used by the state and the resistances mobilized by the segmentary formations. From a theoretical perspective, the aim of the article is to show that the application to our own society of categories traditionally developed to account for other cultures should cease to be a simple metaphor or stylistic resource and become an instrument of observation and interpretation. For this to be achieved, these categories must be transformed and made flexible, which also produces effects on the analysis of these "other cultures". Key words Segmentarity, Politics, Black Movement, Bahia 